\title{
Effect of HCG on testicular function in juvenile rhesus monkeys (Macaca mulatta)
}

\author{
M. Arslan and M. H. Qazi \\ Department of Biological Sciences, University of Islamabad, Islamabad, Pakistan
}

Although information exists on the morphological aspects of the immature and adult monkey testis (van Wagenen \& Simpson, 1965; Baker, 1972) and peripheral plasma testosterone levels in the adult monkey (Goodman, Hotchkiss, Karsch \& Knobil, 1974; Michael, Setchell \& Plant, 1974), little consideration has been given to the functional postnatal differentiation of the testis in nonhuman primates. In the present study, therefore, we describe the histological changes and corresponding changes in testicular and plasma testosterone levels in the testis of young rhesus monkeys treated with HCG.

The 7 juvenile male monkeys used, 10-14 months old and weighing 1.4-1.7 kg, were maintained under standard colony conditions. One testis of each animal was removed under ether anaesthesia on Day 1 of the experiment to serve as the initial control. Four of the unilaterally castrated monkeys received a s.c. injection of 300 i.u. HCG (Physex Leo) per day for 5 days (Days 2 to 6). The other three monkeys received no treatment. On Day 7 , the remaining testis was removed and a weighed portion of the decapsulated gonad was processed for testosterone estimation. A piece from the same testis was fixed in Bouin's solution for histological examination of paraffin-wax sections cut at $8 \mu \mathrm{m}$ and stained with Harris's haematoxylin and eosin. Blood samples were drawn from the saphenous vein of the unanaesthetized animal on Days 1 and 7 , before removal of the testis. Bleeding and surgery were always performed between 10.00 and 11.00 hours.

For the analysis of testosterone, testicular homogenates were extracted with redistilled analytical grade methanol $(1: 25 \mathrm{w} / \mathrm{v})$, centrifuged and the precipitate re-extracted with methanol. The two extracts were pooled. Similarly, plasma aliquots were extracted with methanol $(1: 8 \mathrm{v} / \mathrm{v})$. The tissues were then taken to dryness under nitrogen at $40^{\circ} \mathrm{C}$. The dried extracts were reconstituted with appropriate volumes of the assay buffer. Testosterone was measured by the radioimmunoassay described by van Damme, Robertson, Romani \& Diczfalusy (1973). All plasma and tissue determinations were made in triplicate. Recovery of $\left[{ }^{3} \mathrm{H}\right]$ testosterone and unlabelled testosterone standards added to plasma or tissue homogenates was about $93 \%$. To check the reliability of our extraction procedure, celite chromatography of the samples was carried out as outlined by Abraham (1973), and after extraction of the plasma and tissue homogenates with diethyl ether. The testosterone values obtained by the two methods did not differ significantly.

The histological appearance of the control testes (recovered on Day 1) was fairly uniform in all the animals. As described for monkey (van Wagenen \& Simpson, 1965; Baker, 1972) and man (Vilar, 1970), the seminiferous epithelium was composed of pre-Sertoli cells, gonocytes and a few spermatogonia, while the undifferentiated mesenchymal cells (fibroblasts) and fine stromal tissue constituted the bulk of the intertubular compartment. Unilateral castration did not produce any marked effect either on the weight of the remaining testis (Table 1) or its histological characteristics at the end of the 6-day period, in any of the 3 untreated animals. Administration of HCG resulted in an increase in the testicular weight accompanied by a hyperplasia of the intertubular tissue. In many areas of the testis the interstitial cells were characterized by their large size and eosinophilic cytoplasm. The nucleus of such cells was spherical and contained one or more distinct nucleoli, i.e. a transformation of mesenchymal cells into Leydig cells. Such changes in the intertubular tissue of the testis have been shown to occur at the time of puberty or under gonadotrophic stimulation in other mammalian species, including man (Albert, 1961; Abramovich, Baker \& Neal, 1974). In the HCG-stimulated testis there was also a proliferation of the germinal cells and a number of mitotic figures could be seen in the seminiferous tissue. In 20 transverse sections of the seminiferous tubules examined, the cell counts 


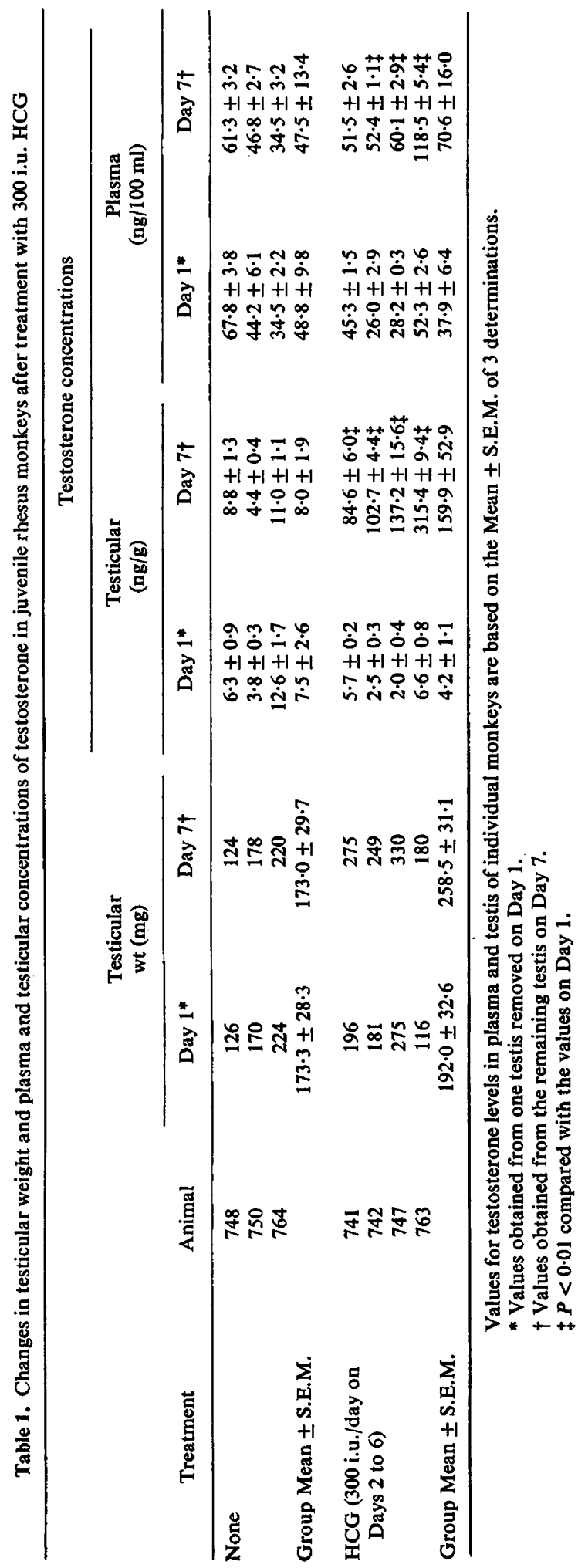


indicated a 3-fold increase in the spermatogonia with a gonocyte to spermatogonium ratio of $1 \cdot 8: 1 \cdot 3$ per section of seminiferous tubule. The equivalent ratio in the untreated animals was $2 \cdot 1: 1 \cdot 3$. The effect of HCG treatment on the seminiferous tubules of the immature monkey may be related to some FSH-like activity in HCG, since even highly purified HCG preparations are known to have some FSH-like activity (Qazi, Mukherjee, Javidi, Pala \& Diczfalusy, 1974), or it could be a consequence of endogenous androgen production.

The testicular and plasma testosterone concentrations were low in the intact juvenile monkeys (Table 1), and changed little after unilateral castration. Similar plasma testosterone values have been reported before the onset of puberty in man (Kelch, Grumbach \& Kaplan, 1972) and in adult castrated monkeys (Goodman et al., 1974; Michael et al., 1974). It is possible that the plasma levels of testosterone in the juvenile monkeys reflect androgen secretion by an extra-gonadal source such as the adrenal cortex. The mean \pm S.E.M. plasma testosterone level was $51 \cdot 3 \pm 10.90 \mathrm{ng} / 100 \mathrm{ml}$ in 3 18- to 24-month-old monkeys which had been castrated for more than 6 months. In HCG-treated animals, the testosterone concentrations in the testicular tissue were 17 to 70 times higher than the values recorded before treatment. These results accord with earlier findings of an HCG-induced stimulation of testosterone production by the testicular tissue (de Jong, Hey \& van der Molen, 1974; Abramovich et al., 1974). In our experiments, the increase in plasma testosterone levels after HCG treatment was about twofold except in one monkey (No. 741) in which there was little difference. The increase in plasma testosterone levels after HCG treatment is reported to be much greater in adult monkeys (Plant \& Michael, 1973) and men (Rosemberg, Crigler, Lee, Jan \& Butler, 1973). It is, therefore, suggested that the HCG-dependent increase in testosterone production may not be reflected as markedly in the peripheral circulation of the juvenile as in the adolescent or the adult.

This study was supported by a grant from the Population Council, New York (M73 056C). We are grateful to Dr E. Diczfalusy, Swedish Medical Research Council, Karolinska sjukhuset, Stockholm 60 , Sweden, for antitestosterone serum.

\section{References}

Abraham, G.E. (1973) Radioimmunoassay of plasma steroid hormones. In Modern Methods of Steroid Analysis, pp. 451-470. Ed. E. Heftmann. Academic Press, New York.

Abramovich, D.R., Baker, T.G. \& Neal, P. (1974) Effect of human chorionic gonadotrophin on testosterone secretion by the foetal human testis in organ culture. $J$. Endocr. 60, 179-185.

Albert, A. (1961) The mammalian testis. In Sex and Internal Secretions, Vol. 1, pp. 305-365. Ed. W. C. Young. Williams \& Wilkins Co., Baltimore.

BAKER, T.G. (1972) Gametogenesis. Acta endocr., Copenh. Suppl. 166, 18-41.

DE JoNG, F.H., HeY, A.H. \& VAN DER MOLEN, H.J. (1974) Oestradiol-17 $\beta$ and testosterone in rat testis tissue: effect of gonadotrophins, localization and production in vitro. J. Endocr. 60, 409-419.

Goodman, R.L., Hotchkiss, J., Karsch, F.J. \& KNOBIL, E. (1974) Diurnal variations in serum testosterone concentrations in the adult male rhesus monkey. Biol. Reprod. 11, 624-630.

Kelch, R.P., Grumbach, M.M. \& Kaplan, S.L. (1972) Studies on the mechanism of puberty in man, In Gonadotropins, pp. 524-535. Eds B. B. Saxena. C. G. Beling \& H. M. Gandy. Wiley-Interscience, New York.

Michael, R.P., Setchell, K.D.R. \& Plant, T.M.
(1974) Diurnal changes in plasma testosterone and studies on plasma corticosteroids in non-anaesthetized male rhesus monkeys (Macaca mulatta). $J$. Endocr. 63, 325-335.

Plant, T.M. \& Michael, R.P. (1973) Testicular function of adult male rhesus monkeys. J. Endocr. 57, xli.

Qazi, M.H., MukherJee, G., Javidi, K., Pala, A. \& Diczfalusy, E. (1974) Preparation of highly purified human chorionic gonadotrophin by isoelectric focusing. Eur. J. Biochem. 47, 219-223.

Rosemberg, E., Crigler, J.F., Lee, S.G., JAN, W.F. \& Butler, P.S. (1972) Response of the human testes to HLH and HCG. In Gonadotropins, pp. 616-627. Eds B. B. Saxena, C. G. Beling \& H. M. Gandy. Wiley-Interscience, New York.

van Damme, M.-P., Robertson, D.M., Romani, P. \& Diczfalusy, E. (1973) A sensitive in vitro bioassay method for luteinizing hormone (LH) activity. Acta endocr., Copenh. 74, 642-658.

VAN Wagenen, G. \& Simpson, M.E. (1965) Embryology of the Ovary and Testis; Homo sapiens and Macaca mulatta. Yale University Press.

VILAR, O. (1970) Histology of the human testis from neonatal period to adolescence. In The Human Testis, pp. 95-108. Eds E. Rosemberg \& C. A. Paulsen. Plenum Press, New York. 